\title{
Article \\ Seed Size, Planting Depth, and a Perennial Groundcover System Effect on Corn Emergence and Grain Yield
}

\author{
Chad L. Kimmelshue ${ }^{1,2}$, Susana Goggi ${ }^{1,2, *(\mathbb{D})}$ and Kenneth J. Moore ${ }^{1(D)}$ \\ 1 Department of Agronomy, Iowa State University, Ames, IA 50011, USA; \\ chadkimmelshue@gmail.com (C.L.K.); kjmoore@iastate.edu (K.J.M.) \\ 2 Seed Science Center, Iowa State University, Ames, IA 50011, USA \\ * Correspondence: susana@iastate.edu
}

check for updates

Citation: Kimmelshue, C.L.; Goggi, S.; Moore, K.J. Seed Size, Planting Depth, and a Perennial Groundcover System Effect on Corn Emergence and Grain Yield. Agronomy 2022, 12, 437. https://doi.org/10.3390/ agronomy12020437

Academic Editor: Jirui Wang

Received: 27 December 2021

Accepted: 3 February 2022

Published: 10 February 2022

Publisher's Note: MDPI stays neutral with regard to jurisdictional claims in published maps and institutional affiliations.

Copyright: (c) 2022 by the authors Licensee MDPI, Basel, Switzerland. This article is an open access article distributed under the terms and conditions of the Creative Commons Attribution (CC BY) license (https:// creativecommons.org/licenses/by/ $4.0 /)$.

\begin{abstract}
The intensive corn (Zea mays L.) and soybean (Glycine max (L.) Merr.) production practices currently used in the Midwestern U.S. concern producers and stakeholders. The negative impact of these two-crop rotations on the environment affects water quality and soil erosion and increases flooding risks. Due to these concerns, cover crops and, specifically, perennial groundcover (PGC) cropping systems have gained greater interest. These perennial species have growing patterns compatible with corn and soybean, and can help rebuild the ecosystem while maintaining good cash crop yields. In addition, producers also are interested in the possible effect of seed size and planting depth on uneven emergence in corn. The successful adoption of PGC systems ultimately depends on the successful corn seedling emergence and consistent yield. The objective of the study was to understand the effects of seed characteristics and placement on emergence, grain yield, and grain quality in corn planted using a Kentucky bluegrass (Poa pratensis L.) (KBG)-PGC and a bare-soil cropping system and to determine grain quality attributes and grain moisture dry-down in a PGC field when compared to a conventional cropping system. Commercially-sized seed and seed sized in the laboratory to represent a narrower seed size distribution were planted in KBG-PGC and bare soil systems at two planting depths $(3.18$ and $6.35 \mathrm{~cm})$. The two-year experiments were planted in a split-plot RCB design with four replications. Individual plants were flagged at emergence, and ears from each plant were harvested individually. Separating the seed lot into different size distributions did not affect seed germination under ideal (standard germination and speed of germination tests) or stressful (cold test) conditions. Seed size distribution also did not influence emergence rate and yield in a conventional tillage (bare soils) or KBG-PGC system. These results indicate that seed sizing specifications and seed size cutoffs currently used by seed companies are suitable for uniform emergence and maximum grain yield in both cropping systems. Seed placement was crucial to uniform emergence in both cropping systems, while seed size distribution did not play a role in emergence for either system. The PGC cropping system delayed seed corn emergence and reduced grain yields as much as $50 \%$. This information is important for those producers considering adopting a PGC system because it demonstrates that uniform planting depth is more important than seed size distribution.
\end{abstract}

Keywords: perennial groundcover (PGC); Kentucky bluegrass (KBG); corn; crop rotation

\section{Introduction}

Modern-day crop producers are concerned with the negative environmental impact of their crop production practices. The use of environmentally protective management practices, such as cover crops, can revert the negative impact of conventional cropping systems on soil erosion, increased nitrogen leaching into ground water, loss of soil structure, and development of herbicide resistant weeds. These cover crops are planted in the offseason to provide cover and reduce soil erosion in times when the cash crop is not growing. The number of acres planted with cover crops in Iowa increased 22\% from 2016 to 2017 
and has increased 50\% since 2012 [1,2]. Perennial groundcovers (PGC), for example, have the advantage of protecting the soil all year long and can be planted with species that grow in the off-season from the cash crop. The benefits associated with any cover crop are enhancing diversity and functionality of the microbial community, reducing soil erosion, increasing nutrient supply to the cash crop, reducing herbicide use, and allowing for crop residue to safely be removed for other uses [3-5]. Maintaining soil coverage after the cash crop is harvested helps protect the soil from environmental factors that cause erosion [6].

Kentucky bluegrass (KBG) is an ideal candidate for a PGC in a corn cash crop system [7-9]. This cool season grass is shade tolerant, goes dormant in the summer when corn is growing, and forms a dense shallow root system [10,11]. These shallow root systems do not compete for resources with deep-rooted crops such as corn during their active growth phase [12]. Their growth pattern allows both species to coexist while not limiting the production of the cash crop [13]. KBG also produces tillers which help reestablish the groundcover that was destroyed with strip tillage at planting or with the use of herbicides prior to planting corn [11].

Crop producers believe that uneven seedling emergence is a result of seed size variation and planting depth precision. This uneven seedling emergence is believed to be the source of lower crop yield [14]. However, results from multiple published research studies are inconclusive. Most studies show that seed size and shape may influence germination in the laboratory [15], but these results are difficult to replicate in the field beyond vegetative growth [16,17]. Graven and Carter [18] determined that emergence, vegetative dry weight, silk date, and grain yield in corn are not influenced by seed size or shape under ideal planting conditions. Only small round seed had a 5-15\% lower emergence under stressful conditions (early planting, no till, and soil crusting). These authors concluded that producers should concentrate on seed genetic potential, seed quality, and seed price rather than seed size/shape, except under stressful conditions $[18,19]$. Seed size also has little effect on the number of days to $50 \%$ emergence, or final percentage emergence, but smaller seeds do produce shorter plants [18]. In their study, planting date and planting depth significantly affected emergence of large and small seeds alike. Deeper and earlier planting resulted in slower emergence regardless of seed size $[18,19]$. These seed characteristics and seed placement studies have been conducted under traditional production practices but none, to our knowledge, in a PGC production system. Seed size and placement may be especially important in these systems where the ground remains covered and soil temperature remains low into the spring [20].

This study aims to identify the necessary factors to manage a successful Kentucky bluegrass perennial groundcover with a corn cash crop. Our hypothesis is that a deeper planting depth will produce delayed corn emergence in both cropping systems. However, a deeper planting depth could be more suitable in a PGC cropping system, as the germinating seed will have less competition from the KBG roots and underground structures. Additionally, a more uniform seed size could result in a more uniform emergence pattern. Our objectives are to identify optimum seed size and placement in both a conventional tillage system and a PGC system to ensure uniform emergence and maximum crop yield and to determine grain quality attributes and grain moisture dry-down in a PGC field when compared to a conventional cropping system. For these experiments, seed is considered the unit sold to producers for planting, while grain is the product harvested by the producer at the end of the growing cycle of the crop.

\section{Materials and Methods}

\subsection{Field Plot Design and Planting}

The field experiments for this study were conducted at the Bruner Research Station $\left(42^{\circ} 00^{\prime} 44.8^{\prime \prime} \mathrm{N} 93^{\circ} 43^{\prime} 57.3^{\prime \prime} \mathrm{W}\right)$ in Boone, Iowa in 2019 and 2020 . Soil at the research site is a Nicollet loam (Aquic Hapludolls, 85\%), Clarion loam (Typic Hapludolls, 10\%), and Webster loam (Typic Endoaquolls, 5\%), which is somewhat poorly drained and has 1-3\% 
slopes. These soils had a $\mathrm{pH}$ of 6.8 , a buffered $\mathrm{pH}$ of 7.0 , and had $3.8 \%$ organic matter. The phosphorus content was $8 \mathrm{ppm}$ and potassium content was $121 \mathrm{ppm}$.

The field experiment was a split-plot design consisting of four 0.036 ha blocks (replications) that were split into two whole plot treatments: groundcover with midnight Kentucky bluegrass (KBG) or bare soil. Eight subplot treatments were planted into each whole plot treatment (KBG cover or bare soil). The eight subplot treatments consisted of two different hybrids subdivided into two different seed sizes and planted at two planting depths $(3.18$ and $6.35 \mathrm{~cm})$. All subplot treatments were tested in combination with other subplot treatments. All treatments were considered fixed, besides blocks, which were considered random.

The KBG groundcover was seeded and established on 12 September 2018. All plots were disked twice with a $4.57 \mathrm{~m}$ John Deere 210 disk (conical blades on $22.86 \mathrm{~cm}$ spacing) prior to seeding of the KBG. The initial pass was parallel to the length of the field, and the second pass was performed at a $45^{\circ}$ angle diagonally. All plots were tilled with a John Deere 680 three-point mounted rotary tiller to a $15.24 \mathrm{~cm}$ depth. All plots were then rolled with a Brillion PPD-7 soil pulverizer/roller after tillage. KBG was planted at $48.2 \mathrm{~kg} \mathrm{ha}^{-1}$ using a Tye Pasture Pleaser (model 104-4204) three-point mounted grain drill with 10 rows on $20.32 \mathrm{~cm}$ spacings at $0.64 \mathrm{~cm}$ depth. An additional $48.2 \mathrm{~kg} \mathrm{ha}^{-1} \mathrm{KBG}$ was planted using a Brillion Sure Stand Seeder (model SSPT-604) three-point mounted broadcast drill. Seeds were broadcast and packed into the upper $0.32-0.64 \mathrm{~cm}$ of soil. The total amount of KBG planted was $96.4 \mathrm{~kg} \mathrm{ha}^{-1}$.

Corn was established in the KBG cover using strip tillage to create a cover-crop free planting area. Strip tillage was accomplished by first using a Unverferth model 330 Ripper Stripper (Unverferth Manufacturing Co., Shell Rock, IA, USA) (four-row, $76.2 \mathrm{~cm}$ spacing) with the ripper shanks running at a $30.45 \mathrm{~cm}$ depth and the coulters running at $10.16 \mathrm{~cm}$ depth. The total strip width was $38.1 \mathrm{~cm}$. Following the Unverferth, a Maschio PTO (Maschio-Gaspardo North America Inc., DeWitt, IA, USA) driven gang tiller was used. The gang tiller has three gangs on $76.2 \mathrm{~cm}$ spacings. The gang tiller was placed directly over the original tillage strips and tilled to a $10.16 \mathrm{~cm}$ depth. Bare soil plots were tilled with John Deere 680 three-point mounted rotary tiller to a $15.24 \mathrm{~cm}$ depth in the spring, 10 days prior to planting.

Tillage occurred perpendicular to the direction in which the Kentucky bluegrass was planted. Each subplot was $3.05 \mathrm{~m}$ wide by $7.62 \mathrm{~m}$ long, consisting of four rows (0.76 m spacing). Fertilizer was applied seven days prior to corn planting. Fertilizer was a combination of diammonium phosphate (DAP) and muriate of potash (MOP), blended together and applied at a rate of $33.63 \mathrm{~kg} / \mathrm{ha} \mathrm{N}, 89.67 \mathrm{~kg} / \mathrm{ha}_{2} \mathrm{O}_{5}$, and $112.09 \mathrm{~kg} / \mathrm{ha} \mathrm{K}_{2} \mathrm{O}$.

Corn was planted with a four-row Kinze 3000 pull type planter (Kinze Mfg., Inc., Williamsburg, IA, USA) at 86,000 seeds ha ${ }^{-1}$. Corn was planted on 24 April 2019 and 24 April 2020. All seed samples were treated with Apron XL (Syngenta, Greensboro, NC, USA) at $5.21 \mathrm{~mL} \mathrm{~kg}^{-1}$ of seed and Maxium 4FS (Syngenta, Greensboro, NC, USA) at $10.43 \mathrm{~mL} \mathrm{~kg}^{-1}$ of seed prior to planting. Emergence date, grain quality, yield, and moisture data were collected at $3.05 \mathrm{~m}$ from the middle of each of the two central rows of each subplot. An additional $168.13 \mathrm{~kg} / \mathrm{ha} \mathrm{N}$, in the form of sulfur coated urea, was applied as a band on the afternoon following corn planting in the morning.

\subsection{Seed}

Seeds graded as "Medium Flat" seed were used in this study from two commonly grown hybrids in central Iowa: 70N16 CNV (Blue River Organic Hybrids, Ames, IA, USA) and P1197 (Corteva, Johnston, IA, USA). 70N16 CNV is a 114-day relative maturity hybrid and P1197 is a 111-day relative maturity hybrid. The same seed lot of 70N16 CNV was used in both 2019 and 2020. Different seed lots of P1197 were used in 2019 and 2020. Seed from each of these lots was resized using an AEC Hand Screen Shaker-TSV 90 (Applied Electronics Corporation, Saint Charles, IA, USA). Both seed lots were first sized by width and second by thickness. For both hybrids, seed with width between $8.33 \mathrm{~mm}$ and $8.73 \mathrm{~mm}$ 
and thickness between $4.76 \mathrm{~mm}$ and $5.16 \mathrm{~mm}$ was kept as the "sized seed" category. For this study, two seed sizes per hybrid were used, either "unsorted seed" in the original bag, or "sized seed" with a narrower seed size distribution. Laboratory evaluations were also performed on the seed remaining after the sorted "sized seed" was separated from the seed lot. This seed size distribution was named "remaining seed".

\subsection{Seed Viability and Vigor}

Seed viability was determined using the Standard Germination Test described in the Rules for Testing Seeds of the Association of Official Seed Analysts (AOSA, 2017). Seed vigor was determined using the Speed of Germination, Seedling Dry Weight, and Cold tests conducted according to the AOSA Vigor Testing Handbook (AOSA, 2009).

\subsection{Standard Germination, and Seedling Dry Weight}

The Standard Germination test was conducted using the rolled paper towel method [21], with minor modifications. Three replications of 50 seeds were germinated at $25{ }^{\circ} \mathrm{C}$ on rolled paper towels (Anchor Paper Co., St. Paul, MN, USA), moistened with tap water and covered with one additional moist paper towel. Paper towels were then rolled up into a cylinder and held in place with a rubber band placed at the base of the cylinder. Each replication from each treatment was placed in a separated container and covered with a plastic bag secured in place with a rubber band. One replication of each hybrid and seed size was randomly placed into a modified food service cart (Lincoln Foodservice Products Inc., Fort Wayne, IN, USA). The carts were placed for germination in a walk-in germination chamber at constant $25^{\circ} \mathrm{C}$ with alternating light cycles (3-h on, 3-h off) for a total of 12-h light per day. Normal seedlings were evaluated on day seven according to the AOSA Rules of Seedling Evaluation Handbook [21]. Normal seedlings were separated from the abnormal seedlings and dead seed and were used for the Seedling Dry Weight test. The seed tissue still attached to the normal seedlings was removed from the roots and shoots. The roots and shoots were then dried at $75^{\circ} \mathrm{C}$ for $16-20 \mathrm{~h}$ [22] inside coin envelopes. Dry seedlings were weighed and the average dry weight per seedling was calculated.

\subsection{Speed of Germination Test}

Speed of germination was conducted separately from the standard germination test, but this test used the same methodology as the Standard Germination Test rolled paper towel method, described in the prior section [21]. Normal seedlings were evaluated daily, according to AOSA Rules [23], starting at day three after planting. After daily evaluation, normal seedlings were removed and recorded, and the remaining un-germinated seeds were returned to the germination chamber, rolled up in the moist paper towels. Final evaluation count was conducted on day seven. Corn seedlings were characterized as "normal" when a minimum of root structure [24] and a minimum of $3.8 \mathrm{~cm}$ shoot growth (combination of coleoptile and first leaf) were observed. Results were analyzed using the following formula [25]:

Speed of Germination index $=$ (number of normal seedlings $/$ days after planting $)+\ldots+($ number of normal seedlings/days of final count (day 7))

to determine the effects of seed size on seed vigor and total germination of corn.

\subsection{Cold Test}

Seed vigor also was evaluated using the tray method cold test [24]. Four 100 -seed sub samples per hybrid were placed on top of one moistened and pre-chilled sheet of crepe cellulose paper (Kimberly Clark, Neenah, WI, USA). The crepe cellulose paper was placed on a fiberglass tray $(45 \mathrm{~cm} \times 66 \mathrm{~cm} \times 2.54 \mathrm{~cm})$ and moistened with $1100 \mathrm{~mL}$ of tap water. The moistened crepe cellulose paper and fiberglass trays were cooled to $10{ }^{\circ} \mathrm{C}$ overnight before planting the seed. After planting, trays were covered with a 4:1 mixture of sand to soil. Trays were placed randomly into modified food service carts (Lincoln Foodservice 
Products) and placed at constant $10^{\circ} \mathrm{C}$ for seven days without light. After this period, carts were moved into a walk-in germination chamber at constant $25^{\circ} \mathrm{C}$ with alternating light cycles (3-h on, 3-h off) for a total of 12-h of light per day for germination. Normal seedlings were evaluated after seven days, according to AOSA Rules [23].

\subsection{Field Measurements}

\subsubsection{Corn Emergence}

Emerged seedlings from the central $3.05 \mathrm{~m}$ of the inner two rows of each plot were flagged daily, and emergence date was recorded. A seedling was considered emerged when its coleoptile emerged at least $1.25 \mathrm{~cm}$ above the soil surface. The flags used were color-coded to facilitate visual identification of emergence date throughout the experiment (Figure 1). Emergence was considered complete after 16 days following the first emergence date recorded for each plot. Any additional plants emerging after day 16 were grouped with day 16 during data analysis. Total days to emergence was computed as the number of days after planting until no further plants emerged. Final emergence percentage was calculated based on the number of seedlings that emerged as a percentage of seeds sown.
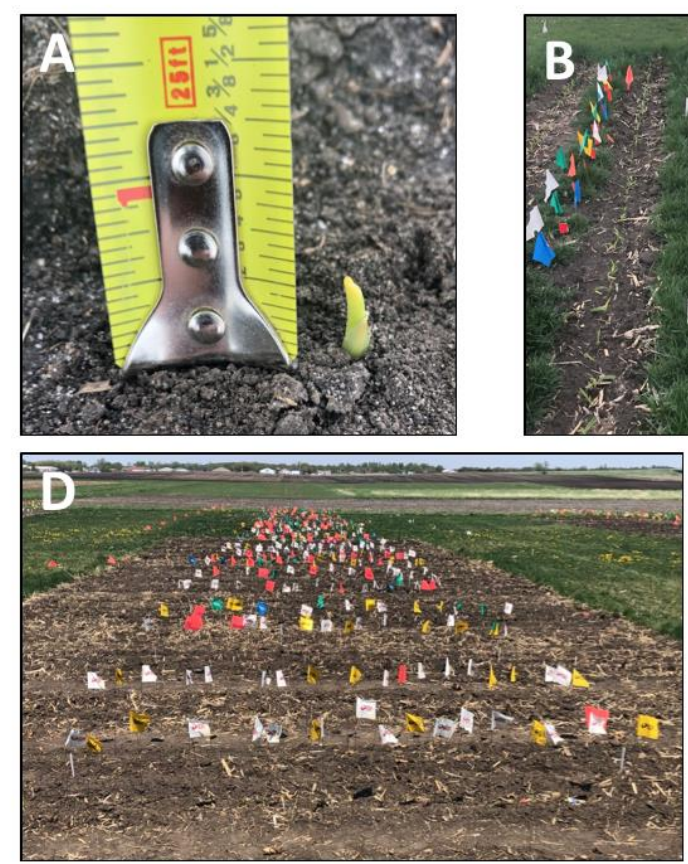
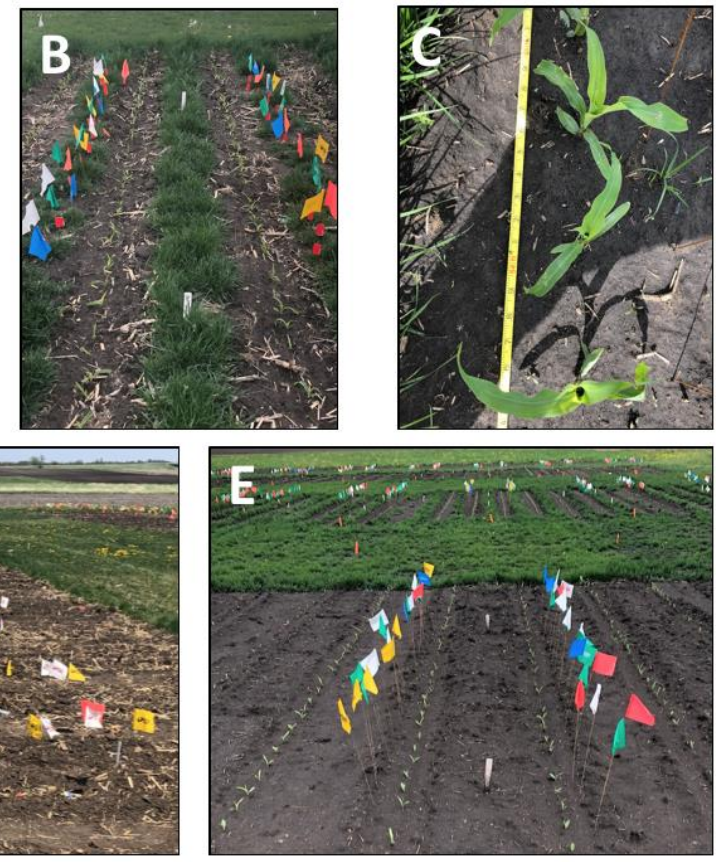

Figure 1. Images of field plots in bare soils and Kentucky bluegrass perennial groundcover systems measuring seedling emergence (A), emergence date color-coded flagging $(\mathbf{B}, \mathbf{D}, \mathbf{E})$, and recording plant-to-plant spacing $(\mathbf{C})$ in the field.

\subsubsection{Harvest and Grain Moisture Content}

Moisture loss of the grain in the field was measured weekly using a SCiO microspectrometer (Consumer Physics Inc., Herzliya, Tel Aviv, Israel) in 2019 and 2020. Data were used to determine grain dry-down differences between ears produced on plants in a KBG-PGC or bare soils. When grain reached maturity, each ear was harvested by hand, tagged, and dried in small-scale laboratory dryers, as described by [26], and dried with forced air at $42{ }^{\circ} \mathrm{C}$ for $48 \mathrm{~h}$. The moisture of each ear was also recorded after drying. Individual plant yield was calculated and normalized to $15 \%$ moisture. Harvest dates were 23 October 2019 and 1 October 2020.

\subsubsection{Grain Quality}

Corn grain moisture, grain protein, oil and starch content, and potential ethanol production were determined in whole grain samples by near-infrared spectroscopy using 
calibrations developed at the Iowa State University Grain Quality Laboratory. The calibrations CN201301 $(2,3,4)[26,27]$ were conducted on the Foss Infratec transmission analyzers that were used for grain composition testing (Foss North America, Eden Prairie, MN, USA).

\subsection{Statistical Analysis}

Statistical analysis for field experiments was performed as a split-plot using the PROC MIXED procedure in SAS (SAS Institute, v9.4, 2013) [28]. Analysis of variance was computed for data from each year. All whole plot and subplot factors were considered fixed, except for blocks, which were considered random. Mean separations were determined at an alpha level $=0.05$ using the least significant difference or contrasts. Interaction terms containing blocks were pooled. Contrasts were used to compare emergence dates, hybrids, seed size, planting depth, and PGC vs. no cover. All tests of significance were made at $\alpha=0.05$ unless otherwise noted.

Statistical analysis for seedling germination and vigor tests was analyzed using the PROC GLM procedure in SAS. All factors were considered fixed except for blocks that were considered random. A completely randomized design was used for the cold test as all subsamples from each sample were placed on the same tray. Results from the standard germination, seedling dry weight, and speed of germination tests were analyzed as a randomized complete block design. Different food service carts represented the different blocks, with one replication of each hybrid and seed size randomly placed into each food service cart. Mean separations for standard germination, cold test, seedling dry weight, and speed of germination were determined at an alpha level $=0.05$ using the least significant difference method.

Statistical analysis for corn grain dry-down was performed using the PROC REG and PROC MIXED procedures in SAS. Lines were fitted using PROC REG, and intercept and slopes of the lines were compared using PROC MIXED. Estimate statements (t-tests) were used to compare specific treatment combinations of interest. Year $\times$ cover was used for intercept and date $\times$ year $\times$ cover was used for slope.

\subsection{Weather}

Weather patterns varied each year of the study. The number of growing degree units base 50 (GDU) accumulated from planting to harvest; however, they were very similar, with accumulations of 3173 and 3052 GDUs in 2019 and 2020, respectively. The GDU accumulation in both years was slightly higher than the average values for the Bruner research farm of 2825 GDUs at harvest. The year 2020 was a dry year, where $38 \%$ of the entire season's rainfall occurred in the first six weeks following planting. Additionally, in 2020, a large wind storm (Derecho) occurred on 10 August. Sustained winds from the storm in Boone, IA were $80 \mathrm{mph}$, with gusts near $100 \mathrm{mph}$. The developmental stage of corn plants in bare soil plots was approximately 3-4 weeks post tasseling (VT) at the time of the storm, and corn in the KBG plots was approximately 2-3 weeks post VT. This wind storm coupled with dry conditions were likely the cause of lower corn grain yields in 2020 . This wind storm delayed corn growth and seed fill by 7-10 days with respect to a normal growth cycle. Plants in several plots had lodged, but very few plants were completely snapped. However, all plots were harvested in 2020 following the wind storm.

Precipitation in 2020 was half the amount recorded in 2019. The total precipitation in 2019 was $760.5 \mathrm{~mm}$, while total precipitation in 2020 was only $389.6 \mathrm{~mm}$. In 2019, average mean air temperature for the six weeks following planting was below the normal average temperature typically recorded at the Bruner research farm. Precipitation from planting to emergence in 2019 was $62.8 \mathrm{~mm}$ of rain, and the average temperature was $11.1^{\circ} \mathrm{C}$. Seed moisture content decreased earlier in the 2020 season and harvest occurred 22 days earlier (1 October) than in 2019 (23 October) (Table 1). This difference in weather conditions caused a significant year effect and year by treatment interaction in the model, and some data were analyzed for each year individually. 
Table 1. Mean temperature and rainfall during corn growing season (April-October) in 2019 and 2020.

\begin{tabular}{ccccccc}
\hline & \multicolumn{2}{c}{ Mean Temperature } & \multicolumn{2}{c}{ Rainfall } & \multicolumn{2}{c}{ GDU } \\
\cline { 2 - 8 } & $\mathbf{2 0 1 9}$ & $\mathbf{2 0 2 0}$ & $\mathbf{2 0 1 9}$ & $\mathbf{2 0 2 0}$ & $\mathbf{2 0 1 9}$ & $\mathbf{2 0 2 0}$ \\
\hline Month & \multicolumn{2}{c}{${ }^{\circ} \mathrm{C}$} & \multicolumn{2}{c}{$\mathrm{mm}$} & \multicolumn{2}{c}{ Base 50 } \\
\hline April & 9.4 & 8.3 & 24.9 & 2.3 & 43 & 85 \\
May & 13.9 & 14.4 & 211.3 & 134.1 & 338.5 & 346.5 \\
June & 20.6 & 22.8 & 100.8 & 39.9 & 622.5 & 729.5 \\
July & 23.3 & 24.4 & 117.1 & 70.9 & 774 & 778.5 \\
August & 21.1 & 22.8 & 33 & 25.9 & 637.5 & 678.5 \\
September & 20 & 16.7 & 115.8 & 81 & 609.5 & 434 \\
October & 8.3 & - & 133.1 & - & 148 & -
\end{tabular}

Planting was 24 April in 2019 and 2020, GDU, Rainfall, and Temperature in April are post planting. Harvest was 23 October in 2019 and 1 October in 2020. GDU in October 2019 are accumulated until harvest. GDU base 50 calculation: (Daily Maximum Air Temperature + Daily Minimum Temperature)/2 - 50.

\section{Results}

\subsection{Seed Standard Germination and Seed Vigor Tests}

There were no differences between sized and unsorted seed (seed in the bag) within each hybrid for the standard germination test, speed of germination test, and cold test results. However, the speed of germination test had a small increase for sized seed over unsorted seed for both hybrids. There was a trend for an increase in the warm germination test for sized seed over unsorted seed from the bag. Sized seed for hybrid 7016CNV and hybrid 1197 increased warm germination rates by 0.16 and 0.06 , respectively, over unsorted seed from their respective bag (Table 2). Sized seed for each hybrid did not affect seedling dry weight when compared to unsorted seed from the original bag. Seed from the same seed lot of hybrid 7016CNV was used both years, thus all seed viability and vigor tests were conducted in 2019 and again post-storage in 2020. The warm germination and seedling dry weight percentages for the "remaining seed" category was not significantly different from the other two seed categories (Table 2). Only the cold germination percentage was significantly lower for the "remaining seed" of hybrid 7016CNV (Table 2). Test results were not significantly different when 2019 and 2020 tests were statistically compared, indicating that viability and vigor did not change over storage time. Two different seed lots were used each year for hybrid 1197. When viability and vigor test results from both seed lots and years were statistically compared, these test results were not significantly different. Sized seed from $7016 \mathrm{CNV}$ had a lower bulk density of $7.68 \mathrm{~kg} / \mathrm{m}^{3}$ and a reduced $80,000-\mathrm{kernel}$ count by $0.66 \mathrm{~kg}$ compared to the unsorted seed from the bag (Table 2). Similarly, for hybrid 1197 , there was a decrease in weight of the $80,000-$ kernel count by $0.51 \mathrm{~kg}$ for sized seed over the original unsorted seed from the bag.

\subsection{Field Measurements}

3.2.1. Combined Growing Seasons

Cover and hybrid were significant for seedling emergence, standardized emergence, and grain yield. As treatment effects differed in each year, the results are discussed according to year. Combined results of both cover systems for 2019 and 2020 can be found in Table 3. A normalized emergence variable was calculated to isolate the effect of planting depths on emergence from the effect of seed size distribution. The normalized emergence forces both datasets at each planting depth to coincide and start on the same date. Seeds sown at $6.35 \mathrm{~cm}$ planting depth emerged four days after those sown at $3.18 \mathrm{~cm}$ depth in 2019, and one day later in 2020. 
Table 2. Hybrid, seed size, and screen size used to re-size the seed within a commercial bag of seed, percentage of seed in each category from total seed in the bag (unsorted seed), weight of 80,000 seeds, bulk density, standard germination test and cold test, seedling dry weight, and speed of germination test results.

\begin{tabular}{|c|c|c|c|c|c|c|c|c|c|c|}
\hline \multirow[b]{2}{*}{ Hybrid } & \multirow[b]{2}{*}{ Size } & \multirow{2}{*}{$\begin{array}{c}\begin{array}{c}\text { Flat Hole } \\
\text { Screen Size }\end{array} \\
\text { Size Kep } \\
\end{array}$} & \multirow{2}{*}{$\begin{array}{c}\begin{array}{c}\text { Round Hole } \\
\text { Screen Size }\end{array} \\
\text { Size Kept }\end{array}$} & \multirow{2}{*}{$\begin{array}{c}\text { Seed Kept } \\
\text { from Bag }\end{array}$} & \multirow{2}{*}{$\begin{array}{c}\text { 80,000 Kernel } \\
\text { Weight }\end{array}$} & \multirow{2}{*}{ Bulk Density } & \multicolumn{2}{|c|}{ Germination } & \multirow{2}{*}{$\begin{array}{l}\text { Seedling Dry } \\
\text { Weight }\end{array}$} & \multirow{2}{*}{$\begin{array}{c}\text { Speed of } \\
\text { Germination }\end{array}$} \\
\hline & & & & & & & Warm & Cold & & \\
\hline & & \multicolumn{2}{|c|}{$\mathrm{mm}$} & $\%$ & kg & $\mathrm{kg} / \mathrm{m}^{3}$ & & & (mg/Seedling) & Index ${ }^{1}$ \\
\hline \multirow{3}{*}{$\begin{array}{c}7016 \mathrm{CNV}^{3} \\
\text { (BR) }\end{array}$} & $\mathrm{Bag}^{2}$ & - & - & 100 & 21.43 & 828.75 & 98 & 97 & 56.42 & 13.47 \\
\hline & Re-sized & $4.76,5.16$ & $8.33,8.73$ & 40 & 20.77 & 821.07 & 97.33 & 97.5 & 55.45 & 13.63 \\
\hline & $\begin{array}{c}\text { Remaining } \\
\text { Seed }\end{array}$ & $<4.76$ & $>8.73$ & 60 & - & - & 96.33 & 89.8 & 55.97 & - \\
\hline \multirow[t]{4}{*}{$1197(\mathrm{P})^{4}$} & Bag & - & - & 100 & 22.84 & 808.61 & 98 & 96.6 & 50.4 & 13.28 \\
\hline & Re-Sized & $4.76,5.16$ & $8.33,8.73$ & 60 & 22.33 & 807.14 & 98.33 & 97.6 & 46.66 & 13.34 \\
\hline & $\begin{array}{c}\text { Remaining } \\
\text { Seed }\end{array}$ & $<4.76$ & $>8.73$ & 40 & - & - & 98 & 95.8 & 49.92 & - \\
\hline & LSD (0.05) & & & & 0.23 & 3.6 & 3.71 & 3.15 & 3.86 & 0.23 \\
\hline
\end{tabular}

${ }^{1}$ Speed of germination index $=$ (number of normal seedlings/days after planting) $+\ldots+$ (number of normal seedlings/days of final count (day 7$\left.)\right) .{ }^{2}$ Seed that was received in the bag ${ }^{3}$ Same seed lot used in 2019 and 2020. ${ }^{4}$ Data is averaged between the seed lots used in 2019 and 2020. Different letters next to values indicate a significant difference at alpha level 0.05. Determined by LSD. 
Table 3. Overall emergence and grain yield means for field experiment in Boone, IA in 2019 and 2020. Normalized emergence was calculated by aligning data to start on the same first emergence date for both planting depths.

\begin{tabular}{|c|c|c|c|}
\hline Treatments & Emergence & Normalized Emergence & Grain Yield \\
\hline & \multicolumn{2}{|c|}{ Days after Planting } & $\mathrm{Mg} / \mathrm{ha}$ \\
\hline \multicolumn{4}{|l|}{2019} \\
\hline \multicolumn{4}{|c|}{ Cover } \\
\hline Bare Soil & 21.38 & 19.32 & $15.60 \mathrm{a}$ \\
\hline KBG & 20.85 & 18.92 & $11.26 \mathrm{~b}$ \\
\hline \multicolumn{4}{|c|}{ Hybrid } \\
\hline 7016CNV & $20.68 \mathrm{a}$ & $18.68 \mathrm{a}$ & $12.44 \mathrm{a}$ \\
\hline 1197 & $21.57 \mathrm{~b}$ & $19.57 b$ & $14.56 \mathrm{~b}$ \\
\hline \multicolumn{4}{|c|}{ Seed Size } \\
\hline Bag & 21.05 & 19.05 & 13.53 \\
\hline $\begin{array}{c}\text { Smaller } \\
\text { Distribution }\end{array}$ & 21.2 & 19.2 & 13.47 \\
\hline \multicolumn{4}{|c|}{ Planting Depth } \\
\hline $3.18 \mathrm{~cm}$ & $19.54 \mathrm{a}$ & 19.54 & 13.49 \\
\hline $6.35 \mathrm{~cm}$ & $22.71 \mathrm{~b}$ & 18.71 & 13.51 \\
\hline \multicolumn{4}{|l|}{2020} \\
\hline \multicolumn{4}{|c|}{ Cover } \\
\hline Bare Soil & $13.65 \mathrm{a}$ & $13.13 \mathrm{a}$ & $11.21 \mathrm{a}$ \\
\hline KBG & $16.69 \mathrm{~b}$ & $16.20 \mathrm{~b}$ & $4.98 \mathrm{~b}$ \\
\hline \multicolumn{4}{|c|}{ Hybrid } \\
\hline 7016CNV & 14.97 & 14.47 & 7.34 \\
\hline 1197 & 15.27 & 14.77 & 9.13 \\
\hline \multicolumn{4}{|c|}{ Seed Size } \\
\hline Bag & 15.33 & 14.83 & 7.83 \\
\hline $\begin{array}{c}\text { Smaller } \\
\text { Distribution }\end{array}$ & 14.9 & 14.4 & 8.67 \\
\hline \multicolumn{4}{|c|}{ Planting Depth } \\
\hline $3.18 \mathrm{~cm}$ & $14.74 \mathrm{a}$ & 14.74 & 8.13 \\
\hline $6.35 \mathrm{~cm}$ & $15.50 \mathrm{~b}$ & 14.5 & 8.36 \\
\hline \multicolumn{4}{|c|}{ Sources of Variation } \\
\hline Cover $(\mathrm{C})$ & * & * & * \\
\hline Hybrid (H) & * & * & * \\
\hline Seed Size (S) & NS & NS & NS \\
\hline Planting Depth (D) & * & - & NS \\
\hline Year $(Y)$ & * & * & * \\
\hline \multicolumn{4}{|l|}{ Interactions ${ }^{1}$} \\
\hline $\mathrm{C} \times \mathrm{Y}$ & * & * & * \\
\hline $\mathrm{H} \times \mathrm{Y}$ & * & * & $*$ \\
\hline $\mathrm{D} \times \mathrm{Y}$ & * & - & NS \\
\hline $\mathrm{C} \times \mathrm{H} \times \mathrm{Y}$ & * & * & $*$ \\
\hline $\mathrm{C} \times \mathrm{D} \times \mathrm{Y}$ & * & - & NS \\
\hline
\end{tabular}

* Significant at the 0.05 probability level. Values followed by different letters are significantly different at $p<0.05$ Mean comparisons were done using contrasts. Contrasts were separate for each year as years was significant. NS $=$ Not Significant. ${ }^{1}$ Only significant interactions are listed in the table.

\subsubsection{Growing Season}

When both cropping systems (KBG and Bare Soil) were included in the statistical analysis, hybrid and planting depth significantly affected overall emergence in 2019 . Seed sown at a depth of $6.35 \mathrm{~cm}$ emerged on average 3.17 days later than seed sown at $3.18 \mathrm{~cm}$ depth (Table 3). Hybrid was also a significant factor affecting both normalized emergence and grain yield. Hybrid 1197 yielded an average of $2120 \mathrm{~kg}$ / ha more than 7016CNV. 
Seed size did not have a significant effect on emergence, normalized emergence, or grain yield (Table 3). The presence of KBG groundcover had a significant effect on grain yield. Bare soil plots yielded an average of $4340 \mathrm{~kg} / \mathrm{ha}$ more than KBG plots. The two-way interactions between seed size and hybrid genetics, planting depths, or cropping systems were not significant, indicating that seed size differences have similar effects across these variables. The interactions between cover $\times$ year and among cover $\times$ hybrid $\times$ year were significant; further analysis was conducted on each year and cropping system individually. These interactions indicate a significant environmental impact on cropping system and hybrid characteristics.

Bare soil plots in 2019 had a similar trend as KBG plots (Tables 4 and 5). Hybrid and planting depth significantly affected emergence. Hybrid also significantly affected the normalized emergence and grain yield. Seed size in the bare soil plots followed the same trend as the KBG plots and did not affect emergence, normalized emergence, or grain yield.

Table 4. Mean emergence and grain yield means for KBG perennial groundcover system in 2019 and 2020. Normalized emergence was calculated by aligning data to start on the same first emergence date for both planting depths.

\begin{tabular}{|c|c|c|c|}
\hline Treatments & Emergence & Normalized Emergence & Grain Yield \\
\hline & \multicolumn{2}{|c|}{ Days after Planting } & $\mathrm{Mg} / \mathrm{ha}$ \\
\hline \multicolumn{4}{|l|}{2019} \\
\hline \multicolumn{4}{|c|}{ Hybrid } \\
\hline 7016CNV & $20.39 \mathrm{a}$ & $18.53 \mathrm{a}$ & 10.5 \\
\hline 1197 & $21.75 \mathrm{~b}$ & $19.27 \mathrm{~b}$ & 11.97 \\
\hline \multicolumn{4}{|c|}{ Seed Size } \\
\hline Bag & 20.75 & 18.88 & 11.02 \\
\hline $\begin{array}{l}\text { Smaller } \\
\text { Distribution }\end{array}$ & 20.95 & 18.95 & 11.47 \\
\hline \multicolumn{4}{|c|}{ Planting Depth } \\
\hline $3.18 \mathrm{~cm}$ & $19.26 \mathrm{a}$ & 19.26 & 11.22 \\
\hline $6.35 \mathrm{~cm}$ & $22.55 \mathrm{~b}$ & 18.55 & 11.3 \\
\hline \multirow{2}{*}{\multicolumn{4}{|c|}{ Hybrid }} \\
\hline & & & \\
\hline 7016CNV & 16.17 & 15.71 & 3.79 \\
\hline 1197 & 17.16 & 16.66 & 6.02 \\
\hline \multicolumn{4}{|c|}{ Seed Size } \\
\hline Bag & 17.11 & 16.64 & 4.54 \\
\hline $\begin{array}{l}\text { Smaller } \\
\text { Distribution }\end{array}$ & 16.7 & 16.17 & 5.42 \\
\hline \multicolumn{4}{|c|}{ Planting Depth } \\
\hline $3.18 \mathrm{~cm}$ & 16.41 & 16.41 & 4.73 \\
\hline $6.35 \mathrm{~cm}$ & 16.99 & 15.99 & 5.23 \\
\hline \multicolumn{4}{|c|}{ Sources of Variation } \\
\hline Hybrid $(\mathrm{H})$ & * & * & * \\
\hline Seed Size (S) & NS & NS & NS \\
\hline Planting Depth (D) & * & - & NS \\
\hline Year $(\mathrm{Y})$ & * & * & $*$ \\
\hline \multicolumn{4}{|l|}{ Interactions $^{1}$} \\
\hline $\mathrm{D} \times \mathrm{Y}$ & * & - & NS \\
\hline
\end{tabular}

* Significant at the 0.05 probability level. Values followed by different letters are significantly different at $p<0.05$. Mean comparisons were done using contrasts. Contrasts were separate for each year as years was significant. NS $=$ Not Significant. ${ }^{1}$ Only significant interactions are listed in the table. 
Table 5. Mean emergence and grain yield means for bare soil system in 2019 and 2020. Normalized emergence was calculated by aligning data to start on the same first emergence date for both planting depths.

\begin{tabular}{|c|c|c|c|}
\hline Treatments & Emergence & Normalized Emergence & Grain Yield \\
\hline & \multicolumn{2}{|c|}{ Days after Planting } & $\mathrm{Mg} / \mathrm{ha}$ \\
\hline \multicolumn{4}{|l|}{2019} \\
\hline \multicolumn{4}{|c|}{ Hybrid } \\
\hline $7016 \mathrm{CNV}$ & $20.92 \mathrm{a}$ & $18.81 \mathrm{a}$ & $14.15 \mathrm{a}$ \\
\hline 1197 & $21.87 \mathrm{~b}$ & $19.87 \mathrm{~b}$ & $17.14 \mathrm{~b}$ \\
\hline \multicolumn{4}{|c|}{ Seed Size } \\
\hline Bag & 21.32 & 19.2 & 15.74 \\
\hline Smaller Distribution & 21.45 & 19.45 & 15.46 \\
\hline \multicolumn{4}{|c|}{ Planting Depth } \\
\hline $3.18 \mathrm{~cm}$ & $19.83 \mathrm{a}$ & 19.83 & 15.76 \\
\hline $6.35 \mathrm{~cm}$ & $22.85 \mathrm{~b}$ & 18.84 & 15.45 \\
\hline \multicolumn{4}{|l|}{2020} \\
\hline \multicolumn{4}{|c|}{ Hybrid } \\
\hline $7016 \mathrm{CNV}$ & 13.91 & 13.38 & 10.26 \\
\hline 1197 & 13.37 & 12.87 & 12.23 \\
\hline \multicolumn{4}{|c|}{ Seed Size } \\
\hline Bag & 13.76 & 13.23 & 10.74 \\
\hline Smaller Distribution & 13.52 & 13.02 & 11.72 \\
\hline \multicolumn{4}{|c|}{ Planting Depth } \\
\hline $3.18 \mathrm{~cm}$ & $13.07 \mathrm{a}$ & 13.07 & 11.31 \\
\hline $6.35 \mathrm{~cm}$ & $14.19 \mathrm{~b}$ & 13.19 & 11.12 \\
\hline \multicolumn{4}{|c|}{ Sources of Variation } \\
\hline Hybrid $(\mathrm{H})$ & * & * & NS \\
\hline Seed Size (S) & NS & NS & NS \\
\hline Planting Depth (D) & $*$ & - & NS \\
\hline Year $(\mathrm{Y})$ & * & * & * \\
\hline \multicolumn{4}{|l|}{ Interactions ${ }^{1}$} \\
\hline $\mathrm{H} \times \mathrm{Y}$ & * & * & * \\
\hline $\mathrm{D} \times \mathrm{Y}$ & $*$ & - & NS \\
\hline
\end{tabular}

${ }^{*}$ Significant at the 0.05 probability level. Values followed by different letters are significantly different at $p<0.05$. Mean comparisons were done using contrasts. Contrasts were separate for each year as years was significant. NS $=$ Not Significant. ${ }^{1}$ Only Significant interactions are listed in the table.

Grain moisture loss or dry-down was recorded starting 15 August 2019. KBG and bare soil plots had the same initial moisture content of approximately $62 \%$. To determine the rate of grain dry-down in each cropping system, a linear model was fitted to these data separately for each cropping system. The $\mathrm{R}^{2}$ value for KBG plots and bare soil plots was 0.93 . There were no significant differences between these cropping systems for grain dry-down, as indicated when comparing the linear model intercepts and slopes. The slope of KBG $(-0.74)$ and bare soil plots $(-0.74)$ indicated an average grain moisture loss of $7.4 \%$ units per week. The final moisture content at harvest was also not different among the two cropping systems.

\subsubsection{Growing Season}

The average grain yield in 2020 was $5.34 \mathrm{Mg} /$ ha less than in 2019. The grain yield decreased an average of $6.28 \mathrm{Mg} / \mathrm{ha}$ in KBG plots and $4.39 \mathrm{Mg} / \mathrm{ha}$ in bare soil plots. No significant difference in overall emergence was observed between the two hybrids, however, KBG groundcover and planting depth did significantly affect overall emergence. Seed sown at a depth of $6.35 \mathrm{~cm}$ emerged on average 0.76 days after seed sown at $3.18 \mathrm{~cm}$. Seed sown in a KBG system emerged on average 3.04 days later than seed sown in a bare soil system. KBG groundcover also had a significant effect on normalized emergence and grain yield. Bare soil plots yielded an average of $6.23 \mathrm{Mg} / \mathrm{ha}$ more than KBG plots. Similar to results observed in 2019, seed size did not have a significant effect on emergence, normalized emergence, or grain yield in 2020 (Table 1). Since the interactions between cover $\times$ year 
and cover $\times$ hybrid $\times$ year were significant in the combined analysis, further analysis was conducted on each year and cropping system individually.

Planting depth significantly affected seedling emergence in bare soil plots in 2020 . Seed sown at a depth of $6.35 \mathrm{~cm}$ emerged on average 1.12 days later than seed sown at $3.18 \mathrm{~cm}$ (Table 5). There were no significant factors in the KBG plots of 2020 (Table 4).

\subsubsection{Treatment Combinations}

The means of the treatment combinations, where the main effects interacted with year and cropping system, were calculated to determine whether specific seed placement (planting depth) and size were more suitable for different cropping systems (KBG and Bare Soil). Hybrid genetics, seed size, and planting depth were separated for each year and cropping system. Hybrid genetics, seed size, and planting depth did not affect grain yield in 2019 or 2020 for KBG plots (Table 1, Tables S1-S4). For both years combined in the bare soil system, a trend was observed in which seed that was sown at the shallow sowing depth of $3.18 \mathrm{~cm}$ yielded more than seed sown at the deeper sowing depth of $6.35 \mathrm{~cm}$ by $0.04 \mathrm{Mg} /$ ha (Table 2, Tables S1-S4). An opposite trend was observed in the KBG plots, where plants from a deeper sowing depth yielded more than those from a shallower sowing depth by $0.21 \mathrm{Mg} /$ ha (Table 1, Tables S1-S4). When seed size was analyzed separately, combined over both hybrids, there was an increase of $0.72 \mathrm{Mg} /$ ha grain yield for sized seed in the KBG cropping system (Table 3, Tables S1-S4). The same trend was observed in the bare soil cropping system, where a $0.06 \mathrm{Mg} /$ ha grain yield increase was observed in sized seed compared to seed directly from the bag (Table 4, Tables S1-S4).

\subsection{Grain Quality}

The year, KBG cover, and their interaction were significant for grain protein content, grain oil content, and potential ethanol production by the grain (Figure 2). A significant increase in grain protein content was observed in the bare soil cropping system in 2019. Protein content in corn grain from plants grown in bare soil was $1.15 \%$ higher than grain produced in KBG ground cover systems in 2019 and $0.41 \%$ higher in 2020. Grain from plants grown in KBG ground cover had a higher potential for ethanol production of 0.0089 $\mathrm{L} / \mathrm{kg}$ over grain from plants grown in bare soil in 2019. A significant difference in grain oil content was observed in 2019 to 2020, but cropping systems did not affect oil content both years.
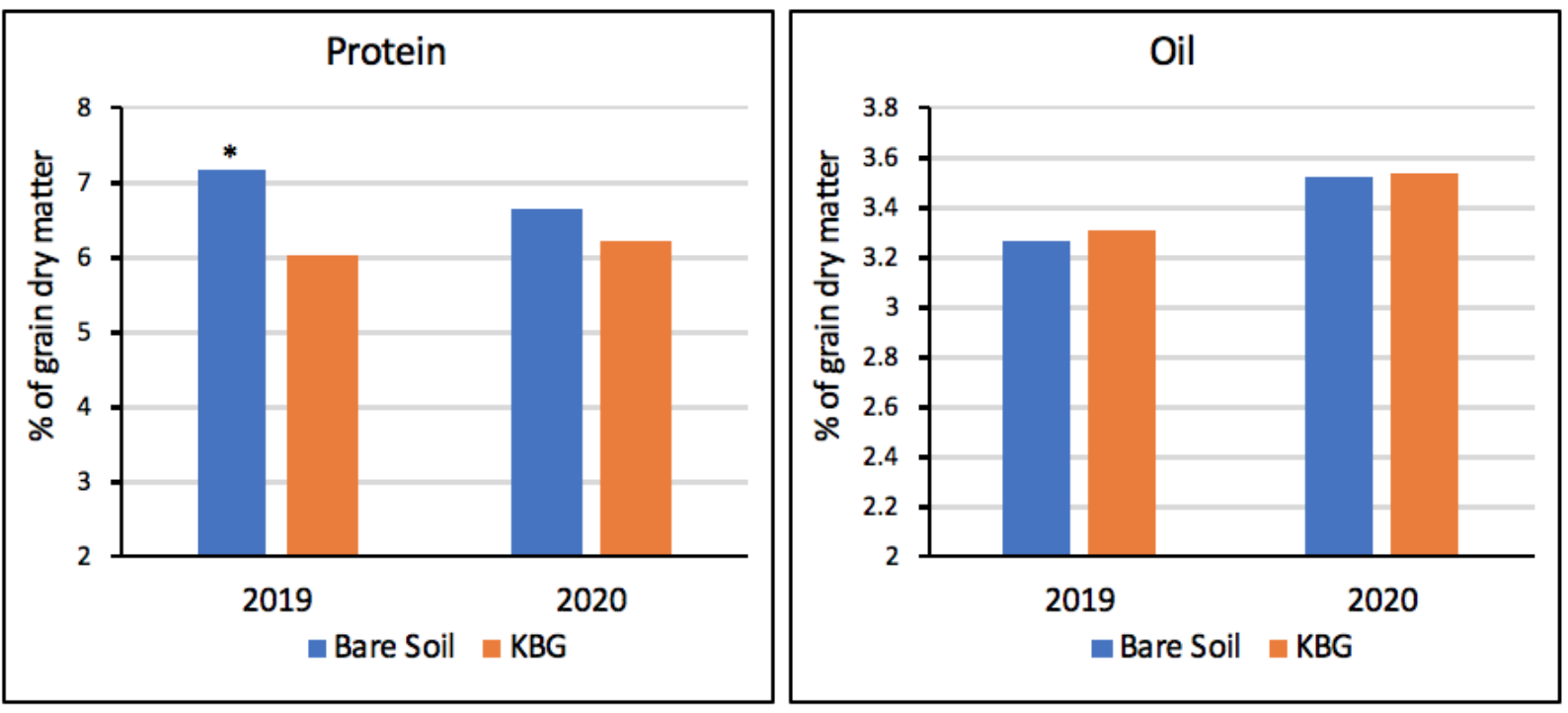

Figure 2. Cont. 

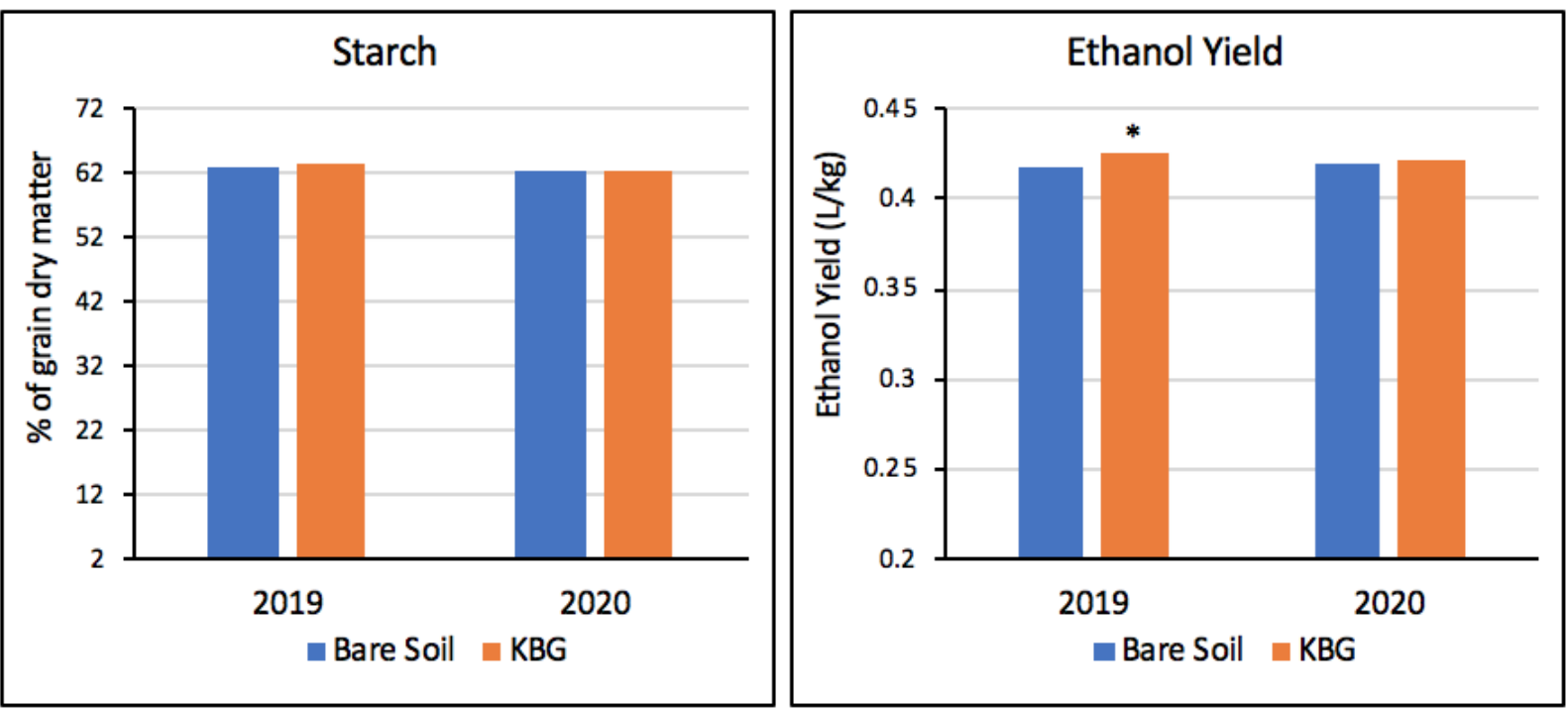

Figure 2. Grain quality analysis for corn grain produced in bare soil (blue bars) and KBG (orange bars) plots. ${ }^{*}=$ significant difference at alpha $=0.05$ level. Mean difference was determined using contrasts for each growing season.

\subsection{Grain Moisture Loss in the Field}

Grain moisture content measurements were initiated on 17 August in both 2019 and 2020. Grain in KBG and bare soil plots had different moisture contents on this initial date (Figure 3). Linear regressions were fitted to these data independently, and both cropping system equations were compared statistically. The intercepts of both were significantly different. The $\mathrm{R}^{2}$ value for KBG plots was 0.84 and bare soil plots was 0.82 . When comparing the slopes, the rate of grain moisture loss in these two cropping systems was not different. The slope for grain moisture loss of KBG $(-0.92)$ and bare soil plots $(-0.83)$ indicated an average moisture loss of 9.2 and $8.3 \%$ units per week, respectively. KBG plots' grain moisture loss rate was more pronounced due to the higher initial grain moisture content. Final moisture content at harvest, however, was not different for the two cropping systems.

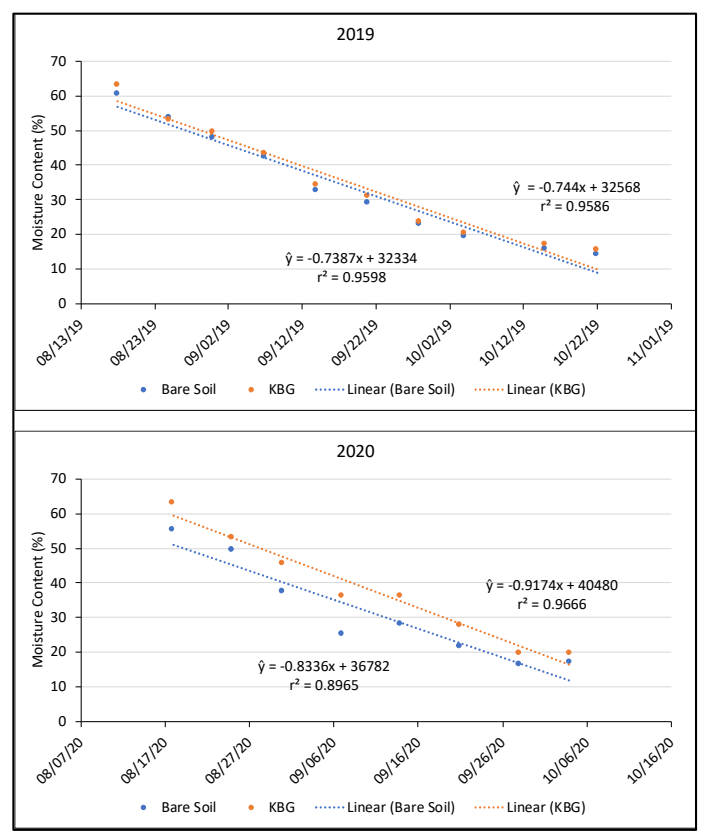

Figure 3. Grain dry-down in the field for corn grain produced in bare soil (blue) and KBG (orange) plots in 2019 (top) and 2020 (bottom). All data were fitted with linear models. 


\section{Discussion}

\subsection{Seed Size}

Seed size distribution did not influence emergence rate and yield in a conventional tillage (bare soils) or KBG-PGC system. The rate of emergence in the field and laboratory was similar for both hybrids, regardless of seed size. Our results confirm that seed germination, emergence patterns, and yield are strongly influenced by seed genetics, seed quality, and environmental conditions and are independent of seed size [29]. The seed lots from both hybrids used in this study were of high quality, as determined by standard germination and vigor laboratory tests. Further separating the seed lot into different size distributions did not affect seed germination under ideal (standard germination and speed of germination tests) or stressful (cold test) conditions. The lower cold germination percentage observed for the "remaining seed" category of 7016CNV could be related to hybrid-specific differences in susceptibility to mechanical damage associated with further conditioning and sizing [29]. Mechanical damage can lower seed germination and vigor $[29,30]$. Seed companies are aware of these genetic differences and minimize seed handling to avoid mechanical stress, especially for susceptible hybrids. A seed lot capable of performing well under stressful cold germination conditions usually also germinates well in the field under non-ideal conditions [31]. As producers plant earlier in the season, they are concerned whether the seed planted can emerge well under stressful conditions, such as cool soils and high moisture. Although producers remain concerned about the use of small seeds and their effect on emergence [14], our study supports other studies that concluded seed size did not inhibit germination, emergence, and yield under these stressful conditions $[18,32,33]$. Our study also confirms that post emergence environmental factors of rain, temperature, plant nutrition, and diseases play a greater role on grain yield than does seed size $[34,35]$. The current commercial seed size separation performed in all seed lots by the seed companies is suitable to obtain uniform stands and the highest yield.

\subsection{Planting Depth}

Low temperatures and high rainfall are known to stress corn seed and possibly caused the observed delayed corn emergence of 17 days after planting. In 2020, the average rainfall following planting was $2.3 \mathrm{~mm}$, the temperature was $15.9^{\circ} \mathrm{C}$, and corn emerged at 11 days after planting. Planting depth had a significant effect on the rate of emergence. As anticipated, seeds planted at a shallower planting depth emerged in a shorter period than those planted at deeper depths. This delayed emergence had no impact on grain yield. Therefore, producers have a range of planting depths that are suitable for both a PGC and bare soil system depending on environmental conditions during planting. The theory that a deeper corn planting depth would provide less competition for nutrients with the shallower KBG roots [12,36] was not supported in our study. Producers may obtain similar grain yields in a KBG system using seed placement between $3.18 \mathrm{~cm}$ and $6.35 \mathrm{~cm}$ (Tables 3-5). However, since planting depth caused an emergence delay, it is important that producers calibrate planters properly to ensure uniform seed placement and uniform seedling emergence. Small variability in planting depth can cause delays in emergence [37]. This delay in emergence can increase plant to plant competition and potential yield loss.

The presence of KBG groundcover delayed emergence and decreased grain yield regardless of planting depth or seed size distribution. This delayed emergence could be the result of several factors. For example, warmer temperature and ideal rainfall recorded could have promoted better emergence in bare soils [38]; KBG was well established and provided good soil coverage, possibly slowing soil warming [39].

\subsection{Kentucky Bluegrass Ground Cover}

KBG was intentionally not chemically suppressed in this study to add an additional stress to the germinating seedling. Consequently, the KBG may have competed with corn for nutrients and water [9]. Corn planted in a PGC system had a delay in emergence and a decrease in grain yield. In our study, this difference could possibly be attributed to not 
suppressing the PGC with chemical or mechanical suppression. KBG was established in the fall of 2018, and therefore, biomass and soil coverage were less abundant when planting corn in 2019 compared to 2020. KBG was at the fourth leaf stage when corn was planted in 2019. Corn thrives when it is in full sun where red wavelength light from the visible light electromagnetic spectrum is approximately 30 percent more than far-red wavelength light [40]. As light is filtered through the canopy, light from the red wavelength is absorbed and only far-red wavelength light filters through, reducing the red:far-red ratio [41]. The higher proportion of far-red wavelength light converts the plant's phytochrome into the inactive form, which in turn slows growth [42]. When corn is in competition with other plant species, such as in our study, the greater proportion of far-red wavelength in the light spectrum may have caused delayed growth [43]. A red:far-red wavelength ratio response is also known to slow germination and growth, as shaded plants became stunted [42,44]. Additionally, post-emergence spring conditions of cooler temperatures and high moisture favored KBG growth and enhanced its competitive advantage over corn and may have led to lower corn yields [45]. The proximity of the groundcover to the corn plant also influences corn yields. The closer the groundcover is to the corn plants, the greater the red:far-red response [44]. Finally, as breeders develop hybrids better adapted to higher density plantings than those used in this experiment, there is a potential for more interplant competition and a greater red:far-red response from late-emerging adjacent corn plants. Finding a proper balance between groundcover benefit and reduced competition with the cash crop is crucial for maintaining good crop yields.

\subsection{Grain Quality}

The grain quality of plants produced in KBG was different from those produced in a bare soil cropping system. The grain grown in KBG plots had lower protein content than grain produced in bare soil plots in both 2019 and 2020. Additionally, grain produced in KBG plots also had greater potential for ethanol production in both years of our study. Although starch concentration in grain was not different between cropping systems, less resistant starch could have been available for enzymes to breakdown, which could have increased the potential ethanol production. The presence of greater amounts of amylose in starch can increase the amount of resistant starch [46]. Resistant starch lowers the conversion of starch into sugars and lowers overall ethanol yields [46,47]. Producers that specifically market their grain to ethanol plants will have a more marketable product, while producers selling their grain for feed may have a slightly less marketable product due to lower protein content.

The change in grain composition could be associated with a wide variety of environmental factors known to affect grain composition [48,49]. Excessive soil moisture can lead to lower grain protein content due to a loss of $\mathrm{N}$ associated with leaching and denitrification [50]. An increase in soil's water holding capacity, as shown in some cover crop species, could have caused the lower grain protein content observed in our study [5,51]. Research into the effect of PGC on grain quality has been limited, and further research is necessary to understand the interaction between crop genetics and a PGC environment. Our study only included two hybrids from the Midwest and traditional management strategies commonly used in this region. Breeders and agronomists should work together to determine genetics and management practices that are suitable for obtaining higher protein content and other desirable grain characteristics when grain is produced in a PGC system. Additional hybrids and management practices could help producers achieve specific grain quality characteristics for target markets while producing grain in a PGC system.

\subsection{Grain Moisture Dry-Down}

Grain dry-down is very important to producers and seed companies alike. Different cropping systems can affect grain dry-down in the field, and this directly affects harvest timing and the need for using driers. In our study, we were interested in directly comparing the KBG-PGC and the bare soil cropping system. We determined that the grain dry-down 
did not differ in plants grown in bare soil and KBG-PGC cropping systems. Although a small difference in the rate of dry-down was observed in 2020, this difference likely could be attributed to a delayed corn emergence in the KGB plots, which resulted in a more immature corn growth stage throughout the growing season. To our knowledge, our research is the first to report on grain dry-down in these differing cropping systems. This information is very important for producers adopting a PGC cropping system because they can be confident that harvest will not be delayed and drying costs will not increase due to grain moisture content. When grain is at high moisture content at the end of the season, harvesting must be delayed or the grain must be artificially dried. The cost associated with artificial drying of grain increases the further the grain moisture is beyond the ideal harvest moisture content (15-20\%). Additionally, early harvest also shortens the exposure of mature grain to inclement weather. A shorter exposure to inclement weather minimizes lodging in hybrids with poor stalk quality and reduces the opportunity for grain pathogen infection in the field [52]. These issues cause a decrease in harvest efficiency of the combine, increase harvest loss, and may complicate grain storage because of pathogen infection $[53,54]$. As our study indicates, producers adopting a PGC system will not experience problems associated with grain dry-down rate, harvest delays, pathogen development, and increased drying costs.

\section{Conclusions}

The results obtained in this study indicate that seed size, sowing depth, and emergence in a PGC and bare soil system do not significantly affect corn grain yield or grain dry-down. Deeper sowing depth causes a significant delay in emergence in both PGC and bare soils, emphasizing the importance of uniform sowing depth and sowing-depth uniformity equipment calibration. Grain protein content decreased and potential for ethanol production increased for plants grown in a PGC system. We conclude that the seed sizing specifications and seed size cutoffs currently used by seed companies are suitable for uniform emergence and maximum grain yield in both cropping systems. However, producers must consider possible changes in grain composition when producing corn for a targeted market in a PGC system.

Corn sown in a PGC system had a delay in emergence and a decrease in grain yield. This difference could possibly be attributed to not suppressing the PGC with chemical or mechanical suppression. Further research is needed to establish the relationship between tolerance to the above-ground biomass of the PGC species and compatibility with the cash crop. Breeding programs should develop improved corn hybrids for this shaded PGC environment, where the crops' negative growth response to shifts in the red:far-red light ratio is limited or non-existent.

As producers are becoming more environmentally sensitive and are using cover crop and PGC systems to protect soils from erosion, it is important to understand how different seed sizes and sowing depths affect seedling emergence and final crop yield. Our study is important to seed producers as well as conservation-minded producers because it defines the variables which are most important to control in a cover crop or PGC system. Future studies should explore how sowing seed corn at greater densities and the ensuing greater interplant competition may affect seedling emergence and crop yields when sowing corn in a PGC.

Supplementary Materials: The following supporting information can be downloaded at: https:// www.mdpi.com/article/10.3390/agronomy12020437/s1, Table S1: Combined treatments mean for a KBG perennial ground cover system separated by year and hybrid. Normalized Emergence was calculated by aligning data to start on the same first emergence date for both planting depths. Table S2: Combined treatments means for a bare soil system separated by year and hybrid. Normalized Emergence was calculated by aligning data to start on the same first emergence date for both planting depths. Table S3: Means for combined planting depths in a KBG perennial ground cover system separated by year and hybrid. Normalized Emergence was calculated by aligning data to start on the same first emergence date for both planting depths. Table S4: Means for combined planting depths in 
a bare soil system separated by year and hybrid. Normalized Emergence was calculated by aligning data to start on the same first emergence date for both planting depths.

Author Contributions: Conceptualization: C.L.K., S.G. and K.J.M.; Formal analysis: C.L.K. and K.J.M.; Funding acquisition: S.G. and K.J.M.; Investigation: C.L.K., S.G. and K.J.M.; Methodology: C.L.K. and S.G.; Project administration: S.G. and K.J.M.; Writing-review and editing: C.L.K., S.G. and K.J.M. All authors have read and agreed to the published version of the manuscript.

Funding: The APC and students were funded by Hatch Projects IOW03814, IOW04114, and IOW05594; hybrid corn seed was provided by Corteva Agriscience and Blue Rivers Hybrids. SCiO microspectrometer moisture meters were provided by Consumer Physics Inc., Herzliya, Tel Aviv, Israel. RegenPGC is supported by Agriculture and Food Research Initiative Competitive Grant No.202168012-35923 from the National Institute of Food and Agriculture.

Institutional Review Board Statement: Not applicable.

Informed Consent Statement: Not applicable.

Data Availability Statement: All data is provided in the form of tables and figures within the article and Supplementary Material.

Acknowledgments: Iowa State University Grain Quality Laboratory for the use of their facilities and Iowa State University Department of Agronomy Research Scientist Roger Hintz for his help with field operations.

Conflicts of Interest: The authors declare no conflict of interest.

\section{References}

1. Juchems, L. Cover Crop Acres Increase but Rate of Growth Declines in 2018. Iowa State Universtiy Extension. 2019. Available online: https:/ / www.extension.iastate.edu/news/cover-crop-acres-increase-rate-growth-declines-2018 (accessed on 14 June 2019).

2. Myers, R.; Weber, A.; Tellatin, S. Opportunites to Improve your bottom line in Row Crops. SARE Ag. Innov. Ser. Bull. 2019, 1-24.

3. Nakamoto, T.; Tsukamoto, M. Abundance and activity of soil organisms in fields of maize grown with a white clover living mulch. Agric. Ecosyst. Environ. 2006, 115, 34-42. [CrossRef]

4. Hall, J.K.; Hartwig, N.L.; Hoffman, L.D. Cyanazine losses in runoff from no-tillage corn in "living mulch" and dead mulches vs. unmulched conventional tillage. J. Environ. Qual. 1984, 13, 105-110. [CrossRef]

5. Hartwig, N.L.; Ammon, H.U. Cover crops and living mulches. Weed Sci. 2002, 50, 688-699. [CrossRef]

6. Moore, K.J.; Karlen, D.L.; Lamkey, K.R. Future Prospects for Corn as a Biofuel Crop. In Compendium of Bioenergy Plants: Corn; CRC Press: Boca Raton, FL, USA, 2014.

7. Fleishman, S.M.; Bock, H.W.; Eissenstat, D.M.; Centinari, M. Agriculture, Ecosystems and Environment Undervine groundcover substantially increases shallow but not deep soil carbon in a temperate vineyard. Agric. Ecosyst. Environ. 2021, 313, 1-7. [CrossRef]

8. Atucha, A.; Merwin, I.A.; Brown, M.G. Long-term Effects of Four Groundcover Management Systems in an Apple Orchard. HortScience 2011, 46, 1176-1183. [CrossRef]

9. Flynn, E.S.; Moore, K.J.; Singer, J.W.; Lamkey, K.R. Evaluation of Grass and Legume Species as Perennial Ground Covers in Corn Production. Crop Sci. 2013, 52, 611-620. [CrossRef]

10. Wennerberg, S.; Skinner, M. Plant Guide-Kentucky Bluegrass (Poa pratensis); USDA-NRCS: Washington, DC, USA, 2007 ; pp. 1-4.

11. Cook, T. Kentucky Bluegrass; Oregon State Universtiy: Corvallis, OR, USA, 2017; pp. 1-7.

12. Moore, K.J.; Anex, R.P.; Elobeid, A.E.; Fei, S.; Flora, C.B.; Goggi, A.S.; Jacobs, K.L.; Jha, P.; Kaleita, A.L.; Karlen, D.L.; et al. Regenerating Agricultural Landscapes with Perennial Groundcover for Intensive Crop Production. Agron. J. 2019, 9, 458. [CrossRef]

13. Dahl, B.E.; Hyder, D.N. Developmental morphology and management implications. Rangel. Plant Physiol. 1977, 4, 257-290.

14. Miller, D. Start Corn Strong: Flagging your yield. Progressive Farmer. Available online: https://www.dtnpf.com/agriculture/ $\mathrm{web} / \mathrm{ag} /$ news/special-features/corn-yield-in-the-beginning/article/2015/12/24/flagging-yield (accessed on 12 January 2020).

15. Varga, P.; Berzy, T.; Anda, A.; Ertsey, K. Relationship between seed harvesting method and seed physiological quality for a number of Pioneer maize hybrids. Maydica 2012, 57, 220-225.

16. Gubbels, G.H. Growth of Corn Seedlings Under Low Temperatures As Affected By Genotype, Seed Size, Total Oil, and Fatty Acid Content of the Seed. Can. J. Plant Sci. 2010, 54, 425-426. [CrossRef]

17. Bockstaller, C.; Girardin, P. Effects of seed size on maize growth from emergence to silking. Maydica 1994, 39, 213-218.

18. Graven, L.M.; Carter, P.R. Seed Size/Shape and Tillage System Effect on Corn Growth and Grain Yield. J. Prod. Agric. 1990, 3 , 445-452. [CrossRef]

19. Nafziger, E.D. Seed Size Effects on Yields of Two Corn Hybrids. J. Prod. Agric. 1992, 5, 538-540. [CrossRef] 
20. Hunter, R.B.; Kannenberg, L.W. Effects of Seed Size on Emergence, Grain Yield, and Plant Height in Corn. Can. J. Plant Sci. 1972, 52, 252-256. [CrossRef]

21. Molatudi, R.; Mariga, I. The Effect of Maize Seed Size and Depth of Planting on Seedling Emergence and Seedling Vigour. J. Appl. Sci. Res. 2009, 5, 2234-2237.

22. Donath, T.W.; Eckstein, R.L. Effects of bryophytes and grass litter on seedling emergence vary by vertical seed position and seed size. Plant Ecol. 2010, 207, 257-268. [CrossRef]

23. AOSA. Rules for Testing Seeds; Association of Official Seed Analysts: Washington, DC, USA, 2017; Volume 1.

24. AOSA. Seed Vigor Testing Handbook; Association of Official Seed Analysts: Washington, DC, USA, 1983.

25. Maguire, J.D. Speed of Germination-Aid in Selection and Evaluation for seedling emergence and vigor. Crop Sci. 1962, 2, 176-177. [CrossRef]

26. Navratil, R.J.; Burris, J.S. Small Scale Dryer Design. Agron. J. 1982, 74, 159-161. [CrossRef]

27. Rippke, G.R.; Hurburgh, C.R., Jr.; Hardy, C.L.; Brumm, T.J. Calibration and field standardization of Perstorp Infratec analyzers for corn and soybeans. In Proceedings of the 7th International Conference on Near-Infrared Spectroscopy, Montreal, QC, Canada, 6-11 August 1995.

28. SAS Institute. SAS Institute Inc. version 9.4 2013.

29. Tabakovic, M.; Simic, M.; Stanisavljevic, R.; Milivojevic, M.; Secanski, M. Effects of shape and size of hybrid maize seed on germination and vigour of different genotypes. Chil. J. Agric. Res. 2020, 80, 381-392. [CrossRef]

30. Pedro, R.; Teixeira, I.R.; Devilla, I.A.; Rezende, R.C.; Carneiro, G. Physiological quality of soybean (Glycine max. L.) seeds during to processing. Agronomia 2011, 32, 1219-1230. [CrossRef]

31. Moore, R.P. Effects of Mechanical Injuries on Viability. In Viability of Seeds; Roberts, E.H., Ed.; Springer: Berlin/Heidelberg, Germany, 1972.

32. Parde, S.R.; Kausal, R.T.; Jayas, D.S.; White, N.D.G. Mechanical Damage to Soybean Seed during Processing. J. Stored Prod. Res. 1998, 38, 385-394. [CrossRef]

33. Copeland, L.O.; McDonald, M.B. Seed Vigor and Vigor Testing. In Principles of Seed Science and Technology; Springer: Berlin/Heidelberg, Germany, 2001.

34. Buyanovsky, G. Climate Effects on Corn Yield in Missouri. J. Appl. Meteorol. Climatol. 2003, 42, 1626-1635.

35. Almaraz, J.J.; Mabood, F.; Zhou, X.; Gregorich, E.G.; Smith, D.L. Climate change, weather variability and corn yield at a higher latitude locale: Southwestern Quebec. Clim. Chang. 2008, 88, 187-197. [CrossRef]

36. Morris, R.A.; Siri-Udompas, C.; Centeno, H.S. Effects of crop proportion on intercropped upland rice and cowpea. Field Crop. Res. 1990, 24, 33-49. [CrossRef]

37. Gupta, S.C.; Schneider, E.C.; Swan, J.B. Planting Depth and Tillage Interactions on Corn Emergence. Soil Sci. Soc. Am. J. 1988, 52, 1122-1127. [CrossRef]

38. Drury, C.F.; Tan, C.S.; Welacky, T.W.; Oloya, T.O.; Hamill, A.S.; Weaver, S.E. Red clover and tillage influence on soil temperature, water content, and corn emergence. Agron. J. 1999, 91, 101-108. [CrossRef]

39. Teasdale, J.R.; Mohler, C.L. Light Transmittance, Soil Temperature, and Soil Moisture under Residue of Hairy Vetch and Rye Agron. J. 1993, 85, 673-680. [CrossRef]

40. Rajcan, I.; Chandler, K.J.; Swanton, C.J. Red-far-red ratio of reflected light: A hypothesis of why early-season weed control is important in corn. Weed Sci. 2004, 52, 774-778. [CrossRef]

41. Holmes, M.G.; Smith, H. The function of phytochrome in plants growing in the natural environment. Nature 1975, $254,512-514$. [CrossRef]

42. Devlin, P.F. Plants wait for the lights to change to red. Proc. Natl. Acad. Sci. USA 2016, 113, 7301-7303. [CrossRef] [PubMed]

43. Afifi, M.; Swanton, C. Maize seed and stem roots differ in response to neighbouring weeds. Weed Res. 2011, 51, 442-450. [CrossRef]

44. Flynn, E.S. Corn Production with Perennial Ground Covers: Evaluation of Cover Species and Their Effects on Corn Growth and Development. Ph.D. Thesis, Digital Repository at Iowa State University, Ames, IA, USA, 2011.

45. Wang, Z.; Huang, B. Physiological Recovery of Kentucky Bluegrass from Simultaneous Drought and Heat Stress. Crop Sci. Turfgrass Manag. 2004, 44, 1729-1736. [CrossRef]

46. Sharma, V.; Rausch, K.D.; Graeber, J.V.; Schmidt, S.J.; Buriak, P.; Tumbleson, M.E.; Singh, V. Effect of Resistant Starch on Hydrolysis and Fermentation of Corn Starch for Ethanol. Appl. Biochem. Biotechnol. 2010, 160, 800-811. [CrossRef]

47. Berry, C.S. Resistant Starch: Formation and Measurement of Starch that Survives Exhaustive Digestion with Amylolytic Enzymes during the Determination of Dietary Fibre. J. Cereal Sci. 1986, 4, 301-314. [CrossRef]

48. DeGeus, Y.N.; Goggi, A.S.; Linda, M.P. Seed quality of high protein corn lines in low input and conventional farming systems Agron. Sustain. Dev. 2008, 28, 541-550.

49. Krueger, K.; Goggi, A.S.; Mallarino, A.P.; Mullen, R.E. Phosphorus and Potassium Fertilization Effects on Soybean Seed Quality and Composition. Crop Sci. 2013, 53, 602-610. [CrossRef]

50. Kaur, G.; Orlowski, J.M.; Motavalli, P.P.; Singh, G.; Golden, B.R.; Nelson, K.A. Impacts and management strategies for crop production in waterlogged or flooded soils: A review. Agron. J. 2020, 112, 1475-1501. [CrossRef]

51. Basche, A.D.; Kaspar, T.C.; Archontoulis, S.V.; Jaynes, D.B.; Sauer, T.J.; Parkin, T.B.; Miguez, F.E. Soil water improvements with the long-term use of a winter rye cover crop. Agric. Water Manag. 2016, 172, 40-50. [CrossRef] 
52. Sacks, W.J.; Kucharik, C.J. Agricultural and Forest Meteorology Crop management and phenology trends in the US. Corn Belt: Impacts on yields, evapotranspiration and energy balance. Agric. For. Meteorol. 2011, 151, 882-894. [CrossRef]

53. Waelti, H.; Buchele, W. Factors Affecting Corn Kernel Damage in Combine Cylinders Factors Affecting Corn Kernel Damage in Combine Cylinders. Trans. ASAE 1969, 12, 55-59.

54. Barney, R.; Price, B.; Sedlacek, J.; SIddiqui, M. Fungal Species composition and abundance on stored corn as influenced by several management practices and maize weevil. Crop Prot. 1995, 14, 159-164. [CrossRef] 